\title{
The influence of environmental factors on the population dynamics, reproductive biology and productivity of Echinogammarus marinus Leach (Amphipoda, Gammaridae) in the Mondego estuary (Portugal)
}

\author{
Paulo Maranhão*, Nuno Bengala, Miguel Pardal, João Carlos Marques \\ Institute of Marine Research (IMAR), c/o Department of Zoology, Faculty of Sciences and Technology, \\ University of Coimbra, 3004-517 Coimbra, Portugal
}

Received 26 October 2000; revised 25 May 2001; accepted 5 June 2001

\begin{abstract}
The population density of Echinogammarus marinus in the Mondego estuary changed throughout the year, with a maximum during spring. The lowest densities were found in the north arm of the estuary, and the highest ones in the inner areas of the south arm. Higher densities appeared associated with the presence of muddy deposits under Fucus vesiculosus (Phaeophyta) and also with the presence of green macroalgae biomass over the sediments. Females were morphologically recognisable at smaller sizes than males, but males became larger than females. Fecundity increases with the size of females and is influenced by temperature and salinity. Sexual activity and recruitment take place continuously throughout the year, although it almost ceases by the end of winter. Present results are in opposition to the hypothesis of discontinuous recruitment presented in a previous study. Productivity (ash free dry weight- AFDW) was estimated at 1.74 to $2.45 \mathrm{~g} \cdot \mathrm{m}^{-2} \cdot \mathrm{year}{ }^{-1}$ in the north arm of the estuary corresponding to an annual turnover ratio $(\mathrm{P} / \bar{B})$ of 4.14 to 6.18 . In the south arm, productivity was estimated at 1.96 to $2.74 \mathrm{~g} \mathrm{AFDW} \cdot \mathrm{m}^{-2} \cdot \mathrm{year}^{-1}$ in the middle section $(\mathrm{P} / \bar{B}$ of 4.68 to 6.56$)$, and at 3.85 to $5.38 \mathrm{~g} \mathrm{AFDW} \cdot \mathrm{m}^{-2} \cdot \mathrm{year}^{-1}$ in the innermost sampling area $(\mathrm{P} / \bar{B}$ of 4.54 to 6.36$)$. Differences in productivity appeared to depend only on population density, while annual $\mathrm{P} / \bar{B}$ ratios were similar over the estuary. Evidence was found that several features of E. marinus population dynamics were dependent on environmental factors resulting from the particular estuary hydraulic regime. () 2001 Éditions scientifiques et médicales Elsevier SAS
\end{abstract}

Echinogammarus marinus / environmental factors / population dynamics / productivity / reproductive biology

\section{INTRODUCTION}

Echinogammarus marinus, a strongly euryhaline amphipod, able to support long emersion periods [43]. is extremely well adapted to life in estuaries. The species distribution extends from Norway to Portugal, having the Mondego estuary as the southern most limit $25,26,27$

In the Mondego estuary, E. marinus is the most abundant species in hard substrate intertidal communities [28]. It constitutes an important prey for upper trophic levels, namely for birds [38.39], therefore playing an important role in the trophic web energy transfers. E. marinus occurs in close association with Fucus vesiculosus, a brown macroalgae, which constitutes an eulittoral belt on hard substrates. Rocky

*Correspondence and reprints: fax +351 239823603.

E-mail address: pmimar@ ci.uc.pt (P. Maranhão). margins make up about $60 \%$ of the perimeter of the Mondego estuary, representing therefore a significant part of the intertidal area, and are essentially the result of the installation of human activities (harbour facilities, aquaculture farms, salt works). E. marinus is typically found underneath Fucus, in association with muddy deposits, being less common on clean sands [26].

During the last decade seasonal intertidal macroalgae blooms (mainly of Enteromorpha spp.) have been reported in the south arm of the Mondego estuary due to nutrient enrichment of estuarine waters $[14,24,31$, 32, 40, 41]. This benthic eutrophication has been giving rise to qualitative changes in the Mondego estuary benthic community [24].

In Europe some studies were already carried out on different aspects of E. marinus biology and ecology $[25,26,43,47,48]$ A previous study on the biology, 
population dynamics, and productivity of E. marinus in the Mondego estuary was carried out in 1986/87 27]. The major results of this study were: seasonal change of E. marinus population density, with maximum during spring and summer, continuous sexual activity throughout the year, being the recruitment described as discontinuous. Based on recognition of cohorts the authors performed the estimation of $E$. marinus lifespan (ten to twelve months), growth production (6.36 to $8.81 \mathrm{~g} \mathrm{AFDW} \cdot \mathrm{m}^{-2}$.year ${ }^{-1}$ ) and other life cycle traits (iteroparous females; semi-annual species). However, monthly sampling periodicity then used was not fully adequate [15] and consequently some assumptions could be incorrect.

Uncertainties about the biological cycle of E. mari$n u s$, and the possible effect of the ongoing eutrophication process lead to a new field study carried out in 1994/95. The purpose was to enlighten the response of E. marinus population features to environmental factors, namely comparing the two arms of the estuary, and to produce more reliable information on the contribution of this abundant species to the estuarine food web.

\section{MATERIALS AND METHODS}

\subsection{Study area}

The Mondego estuary consists of two arms, north and south, that become separated by an island at the estuarine upstream area, at about $7 \mathrm{~km}$ from the sea, joining again near the mouth (figure- $)$ ). The two arms of the estuary present very different hydrographical characteristics. The north arm is deeper (5 to $10 \mathrm{~m}$ during high tide, tidal range about 2 to $3 \mathrm{~m}$ ), while the south arm ( 2 to $4 \mathrm{~m}$ deep, during high tide) is almost silted up in the upstream areas, which causes the freshwater of the river to flow essentially by the north arm. The water circulation in the south arm is mostly due to tides and to the relatively small freshwater input of a tributary, the Pranto River, which is artificially controlled by a sluice, located at $3 \mathrm{Km}$ from the confluence with the south arm of the estuary (foure - 7 ). In addition, due to differences in depth, the penetration of the tide is faster in the north arm, causing daily changes in salinity to be much stronger, whereas daily temperature changes are higher in the south arm [28. 29].

\subsection{Field programme}

The E. marinus population was followed for 13 months at three sampling stations, one in the north arm and two in the south arm (figure $)$. Results from previous studies were taken into account in defining the sampling strategy. Sampling stations were located in order to represent different conditions where $E$. marinus occurs in the estuary. Sampling was performed during low tide, which facilitated the access to the sampling sites. Samples were taken fortnightly from November 1994 to December 1995. Five replicates were taken randomly each time at each station. Each replicate was obtained by scraping the rocky surface where the algae were attached. In addition, the superficial $1 \mathrm{~cm}$ sediment layer around the rocks,

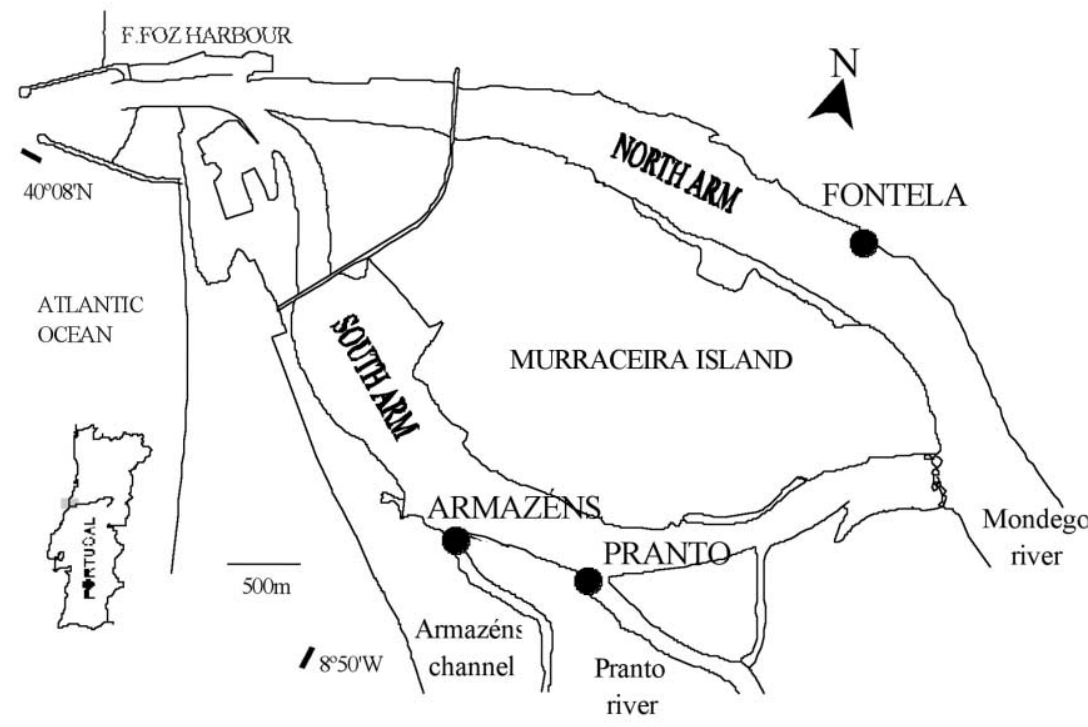

Figure 1. The Mondego estuary: location of the sampling stations in both arms. 
under the fronds of algae, was also taken to ensure that all amphipods on the sampled area were collected. Since the sampled surface was irregular the area was estimated by projecting its shape onto a sheet of polyethylene, which was later weighed. Samples were preserved in $4 \%$ buffered formalin, and later sieved in the laboratory through a $0.5 \mathrm{~mm}$ mesh size bag. Given the size of newly hatched juveniles, this mesh size retains all individuals [27]. After separation, amphipods were kept in $70 \%$ ethanol for posterior analysis. At each sampling date and at each site, salinity, temperature, dissolved oxygen, $\mathrm{pH}$, nitrites, nitrates, and phosphates in the water column were determined. Salinity, temperature, dissolved oxygen and $\mathrm{pH}$ were measured in situ, while water samples were taken from puddles around the algae for nutrient analysis. Sediment samples were also collected to estimate the organic matter content.

\subsection{Laboratory procedures}

Amphipods were counted, sexed, and the cephalic length $\left(C_{\mathrm{L}}\right)$ was measured to the nearest $0.02 \mathrm{~mm}$.

The determination of sex was based on the presence or absence of oostegites and/or broods (females), and of genital papillae (males). Animals without these features were considered to be juveniles. Nonbrooding females were examined for the presence or absence of setae on the oostegites and classified as mature or resting females. If broods were present, eggs were counted, to estimate fecundity, measured and examined to determine the development stage. Five stages were considered, taking into account the criteria described in Skadsheim [47]] adapted by Marques and Nogueira [27], respectively: A, newly laid eggs, spherical grouped and resembling a gelatinous mass; $\mathrm{B}$, eggs well separated, oblong internally homogeneous; C, embryo comma-shape with vestigial pereopods already visible; D, constriction of the comma clearly visible, appendages segmented and looking slender, eyes visible, cephalotorax orange-red; E, hatched and free juveniles (these may stay some days in the brood pouch). Due to some difficulties in distinguishing stages $\mathrm{A}$ and $\mathrm{B}$, data regarding these two stages were pooled in an AB stage. Since eggs become oval in shape during development, an average of their length and width was taken as measurement of their size.

The biomasses of $F$. vesiculosus, green macroalgae (mainly Enteromorpha spp.), and red macroalgae (mainly Gracillaria spp.), were estimated. Algae species were separated, dried at $60^{\circ} \mathrm{C}$ for $48 \mathrm{~h}$, and their dry weight determined. The same procedure was followed to determine sediment dry weigth. Afterwards the ash free dry weight of plants and the organic matter content of sediments were calculated after muffled for $8 \mathrm{~h}$ at $450^{\circ} \mathrm{C}$.

\subsection{Data analysis}

Principal component analysis (PCA) was used to identify the major sources of variation in the physicochemical and biotic data [23]. Data were organised into a matrix of 11 variables (temperature, salinity, dissolved oxygen, $\mathrm{pH}$, nutrients [nitrates, nitrites, and phosphates], percentage of organic matter in sediment, $F$. vesiculosus biomass, green macroalgae biomass, and red macroalgae biomass) $\times 81$ samples. This matrix was standardise to make the variances independent of the means [23]. Correlation matrices were calculated using the Pearson's coefficient and a cophenetic correlation coefficient is determined [23]. Data analysis was performed using the NTSYS-PC (Numerical Taxonomy and Multivariate Analysis) version 1.80 software package [45]

Stepwise, least squares multiple regression models for E. marinus were developed to examine the relationship between some E. marinus population features (density, biomass, sex-ratio, percentage of ovigerous females and fecundity) and environmental factors: physicochemical factors and macroalgae biomass (F. vesiculosus, green macroalgae and red macroalgae). Normality of the distributions and the equality of variances were analysed using respectively the Kolmogorov-Smirnov and Bartlett's tests. When necessary a ln $(1+x)$ transformation was used prior to analysis. Regressions were estimated using the Stepwise Forward Analysis method performed with the STATGRAPHICS 4.0 statistical package.

Annual production $(P)$ was estimated using the Hynes average cohort method modified by Benke [2] essentially to address multivoltine populations, and called the size-frequency method by Waters and Hokenstrom [34]:

$$
P=\left[i \sum_{1}^{i}\left(\bar{d}_{\mathrm{j}}-\bar{d}_{\mathrm{j}+1}\right) \times \sqrt{\left(\bar{w}_{\mathrm{j}} \times \bar{w}_{\mathrm{j}+1}\right)}\right] \frac{12}{C P I}
$$

where: $i$, number of size classes; $\bar{d}_{\mathrm{j}}$, mean density in size class $\mathrm{j}$ (ind $\left.\cdot \mathrm{m}^{-2}\right) ; \bar{w}_{\mathrm{j}}$, mean individual weight in size class $\mathrm{j}\left(\mathrm{mg}_{\mathrm{AFDW}}\right) ; \mathrm{CPI}$, cohort production interval (months).

The mean individual ash free dry weight $(W)$ in each size class $\left(\bar{w}_{\mathrm{j}}\right)$ is obtained from the allometric equation, $W(\mathrm{mg})=1.592924 \times C_{1}^{3.984435}$, determined by Marques and Nogueira [27]

The Hynes method does not require the recognition and tracking of individual cohorts. Therefore, it is suitable for populations with continuous reproduction and no synchronisation of larval release and egg extrusion [33]. The Hynes method for estimating production of aquatic invertebrates involves first an 

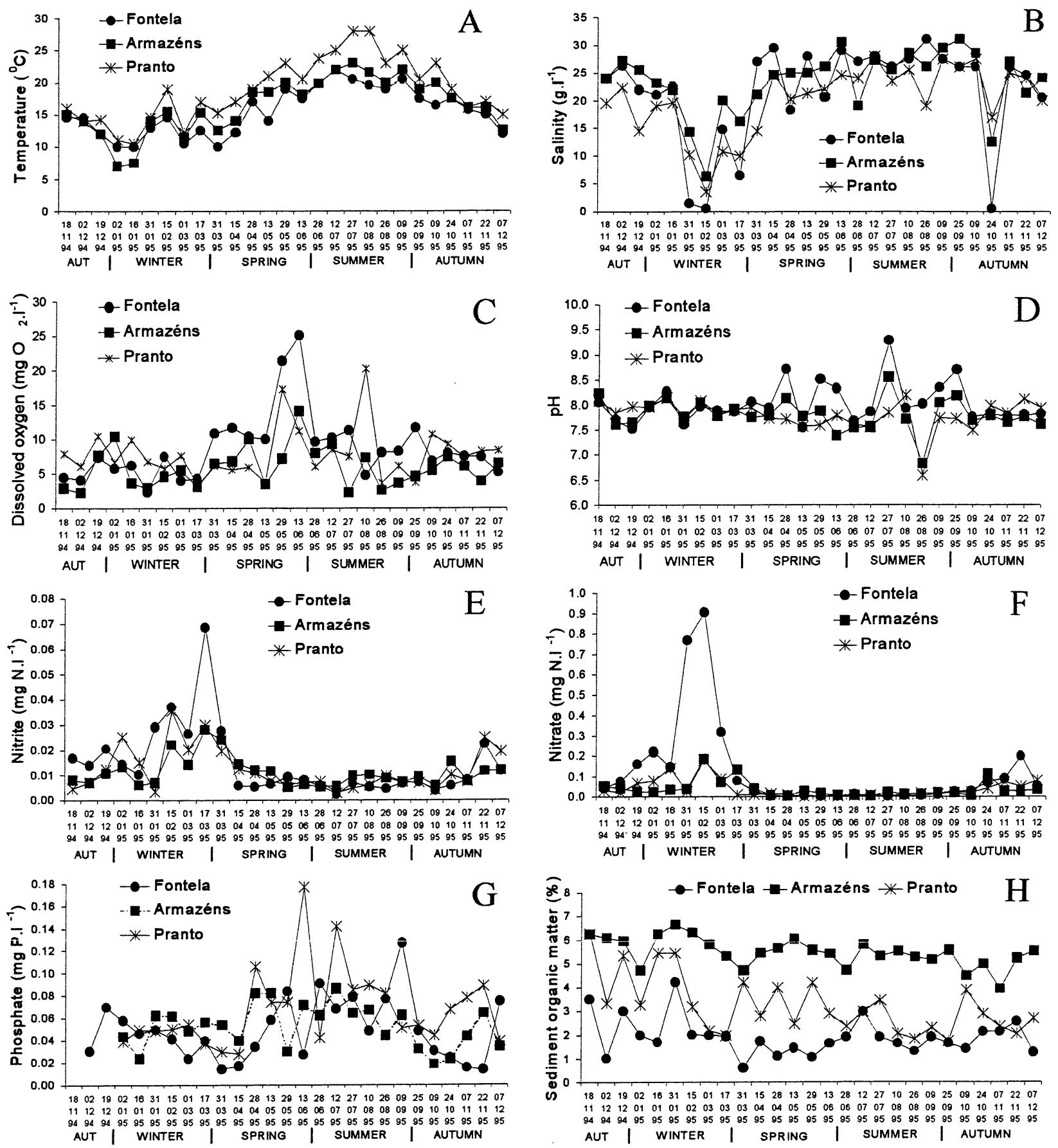

Figure 2. Variation of physicochemical conditions throughout the study period, at the three sampling places. A. Temperature, B. Salinity, C. Dissolved oxygen, D. pH, E. Nitrite concentration, F. Nitrate concentration, G. Phosphate concentration, H. sediment organic matter. 
estimation of the total number of individuals that developed into each size class and then the calculation of losses in numbers between size classes. Production is then estimated as the sum of biomass losses between successive size classes. The total production value obtained was multiplied by a cohort production interval $(C P I)$ correction factor [2], where the $C P I$ is the time interval from hatching to the attainment of the largest size class Based on previgus studies (Vlasblom in Saint-Marie [27]. [46]_[47]), a CPI of 10-14 months was assumed.

\section{RESULTS}

\subsection{Environmental factors}

Large seasonal and spatial variations in physicochemical and biological conditions were observed in the study area (figure 2, 3). Water temperature and salinity (figure $2 A, B$ ) were strongly influenced by season changing from maxima in summer to minima during winter, in both arms of the estuary. Higher water temperatures recorded in the south arm during the study period were most certainly a consequence of the sampling procedures. In fact, despite all sampling was carried out during the morning, we always sampled first at Fontela and afterwards, $2 \mathrm{~h}$ later, at the Pranto station. Dissolved oxygen (foure 20 ) reached the highest values in spring and summer, in both arms. Such values apparently resulted from the occurrence of large quantities of green macroalgae biomass, recorded in this period, in both arms (figure $3 B$ ). During the day, due to photosynthetic activity, green macroalgae contribute to increasing dissolved oxygen and the fact that all measures were taken during the morning is most probably the reason of these observations. The $\mathrm{pH}$ values (figure $2 \mathrm{D}$ ) presented low variation during autumn and winter, but during spring and summer we could observe considerable oscillations. Nitrites and nitrates concentration in the water column (figure 2E. E) exhibited a seasonal variation, reaching higher values during autumn and winter, in both arms. Due to an increase in precipitation, during winter, great amounts of leaching waters (enriched with nutrients) from rice fields located upstream from the estuary were discharged, joining the natural freshwater runoff of the Mondego River. Phosphate concentration in water (figure 2G) reached higher values during the warmer period. This is normally observed in temperate estuaries like the Mondego [40] and is due to phosphorus release from the sediments to the water column in warmer periods [49]. The muddy sediment of Armazéns presented the higher percentage of organic matter content, while coarse sediments of Fontela presented the lowest values (foure 2H). F. vesiculosus biomass (foure $3 \mathrm{~A}$ ) showed an increase
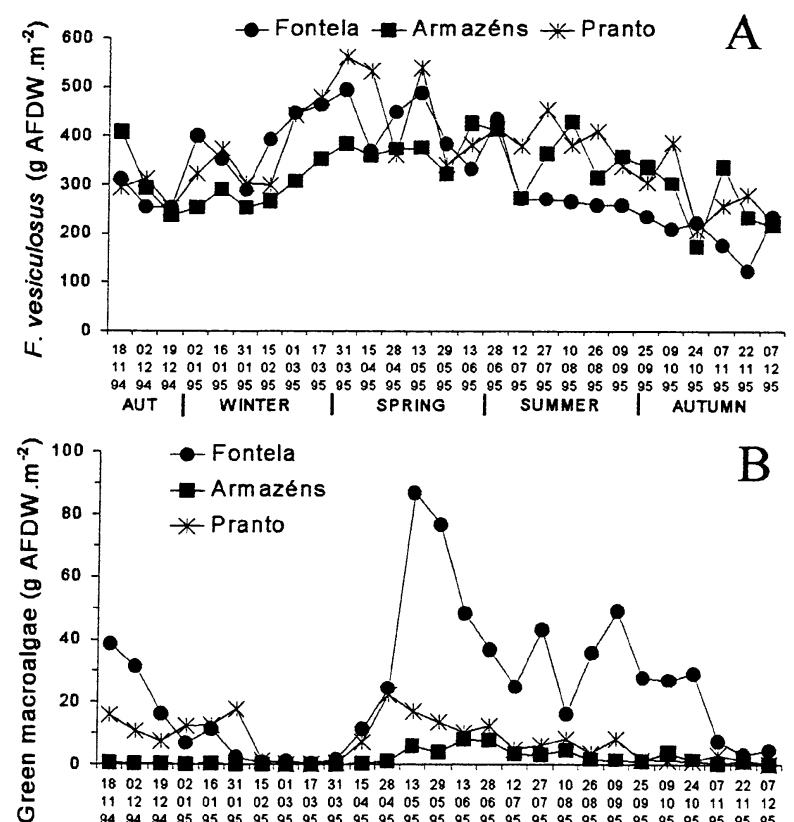

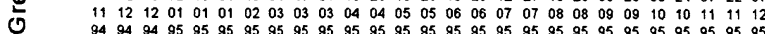
AUT | WINTER | SPRING | SUMMER | AUTUMN

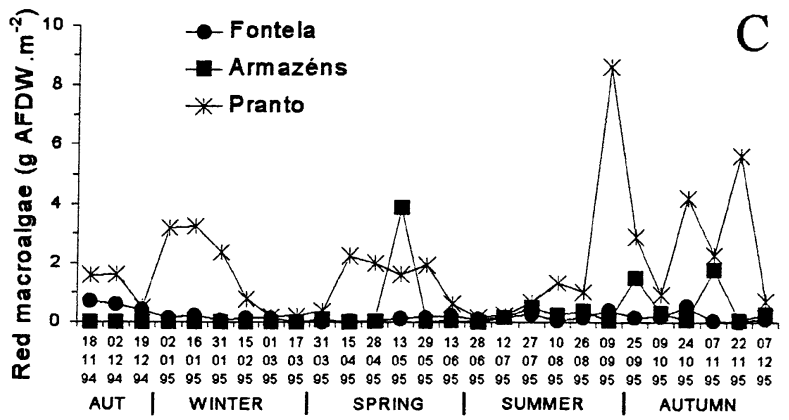

Figure 3. Biomass variation of $F$. vesiculosus (A), green macroalgae (B) and red macroalgae (C) throughout the study period, at the three sampling places.

during winter, reaching the highest values in spring, and a decrease along the rest of the year, in both arms. The occurrence of green macroalgae along the sampling period presented clear seasonal variation. The biomass of green macroalgae (fgure $3 B$ ) was higher during spring and summer, and practically absent in winter. In fact, during the winter, the decrease of salinity, due to precipitation and an increase of current velocity do not allow the normal fixation and development of these algae. Red macroalgae (figure 3d) were practically absent from the north arm, reaching the highest values at the Pranto sampling station, but its biomass was always quite low.

Principal component analysis of the environmental factors $\mathrm{x}$ sampling stations dates matrix reveals a 
consistent pattern (foure 4). This figure represents the projection of environmental factors (descriptors) and sampling stations (objects) in the same diagram (biplot). The projection of a descriptor on a principal axis shows its positive or negative contribution to the position of the objects along the axis [23]. From the projection against the first three axes of variability, it could be observed the existence of clear spatial and seasonal differences. Along the first axis of variability, samples collected during spring and summer were clearly separated from samples collected during autumn and winter. Spring and summer samples were mainly characterised by higher green macroalgae biomass and by higher values of temperature, salinity, dissolved oxygen, and phosphorus concentration in water column. Autumn and winter samples were mainly characterised by higher concentrations of nitrites and nitrates in the water column. The second axis of variability allowed us to separate north arm sampling dates from samples collected in the south arm stations. North arm samples are mainly characterised by higher values of green macroalgae biomass, and by higher concentrations of dissolved oxygen, nitrites, and nitrates in the water column. The higher values of
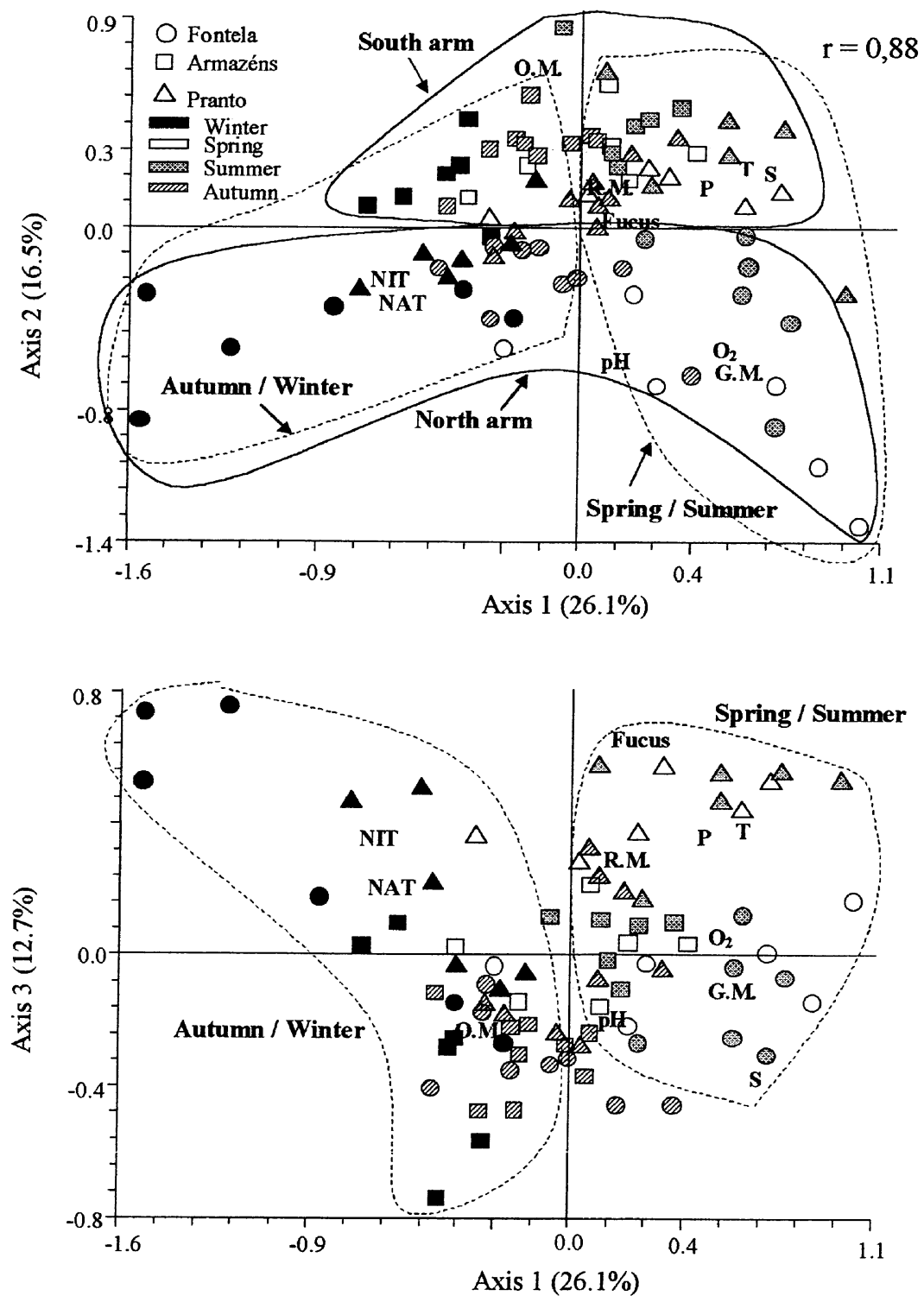

Figure 4. Principal component analysis (PCA) projection of the descriptors and sampling sites of the Mondego estuary in the space defined by the first three axes of variability. NIT: nitrites; NAT: nitrates; O.M.: percentage of organic matter in sediment; $\mathrm{O}_{2}$ : dissolved oxygen; G.M.: biomass of green macroalgae; R.M.: biomass of red macroalgae; P: phosphate; T: temperature; $\mathrm{S}$ : salinity. The percentage of variability associated with each axis is indicated in parentheses. $r=$ cophenetic correlation coefficient. 
green macroalgae biomass observed in the north arm were, to a certain extent, unexpectedly high when compared with those quantified in the south arm. Indeed, in the north arm, due to strong river current, green macroalgae can only find suitable places for fixation and development near the rocky margins, while in the south arm, due to low hydrodynamics, green macroalgae normally occur on the muddybanks, where they can reach massive amounts of biomass $\left(\approx 400 \mathrm{~g} \cdot \mathrm{afdw}^{-2} \mathrm{~m}^{-2}\right)\left[\begin{array}{llll}24 & 31 & 40 & 41\end{array}\right]$. In our case, samples were taken close to the rocky margins, which explains the higher than expected amounts of algae found in the north arm station. The south arm samples are mainly characterised by higher values of temperature, salinity, organic matter in the sediments, phosphorus concentration in the water column, and by large red macroalgae biomass.

\subsection{Abundance}

Population density and biomass changed seasonally, with a winter peak in the Pranto station, and another during spring at all sampling stations (figure 5). Density was lower in the north arm, reaching the highest values in the upstream areas of the south arm. In addition, in the south arm, abundance was clearly higher in the innermost sampling station.
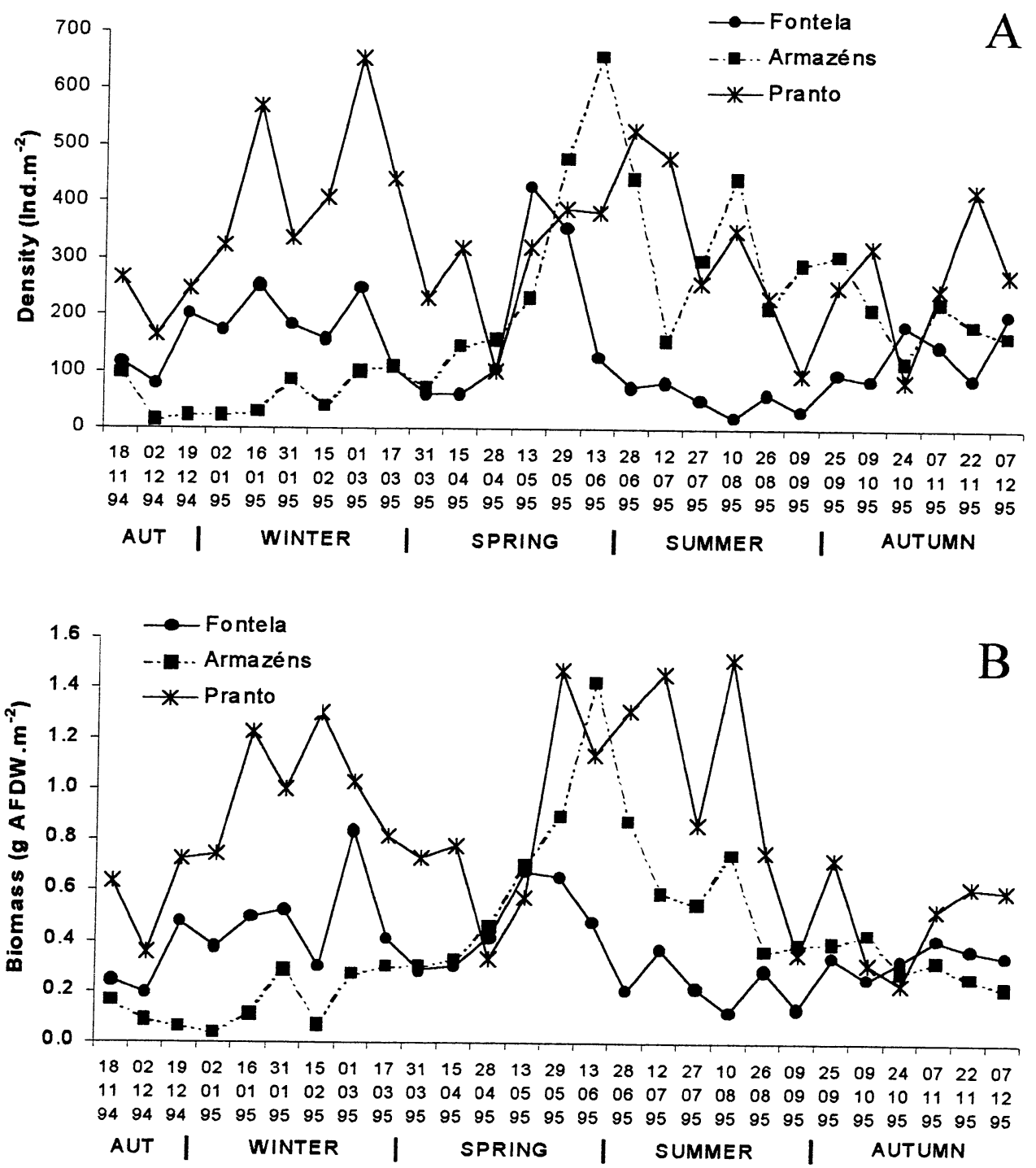

Figure 5. Echinogammarus marinus. Density (A) and biomass (B) at the three sampling places. 
Stepwise multiple regression analysis showed that density and biomass of $E$. marinus were correlated with environmental factors. At the Fontela station, density $(D)$ was negatively correlated with water temperature $(T E M P)$ and salinity $(S A L)$ and positively correlated with green macroalgae biomass $(G M B)$ $(r=0.74 ; \quad P<0.0001)$, and biomass $(B)$ was also negatively correlated with temperature and positively with green macroalgae biomass $(r=0.48 ; P<0.05)$ :

$$
\begin{aligned}
\ln (1+D) & =7.13-0.14 \text { TEMP }-0.04 \text { SAL }+0.02 G M B \\
B & =0.74-0.03 \text { TEMP }+0.003 G M B
\end{aligned}
$$

At the Armazéns station E. marinus density $(r=0.82$; $P<0.0001)$ and biomass $(r=0.85 ; P<0.0001)$ were positively correlated with green macroalgae biomass:

$$
\begin{aligned}
D & =92.38+55.43 G M B \\
B & =0.21+0.15 G M B
\end{aligned}
$$

\subsection{Population structure}

Size-frequency distributions were analysed to interpret the population structure. The same pattern was observed in the three sampling places. Small individuals mainly constitute the population, with juveniles representipg almost always more than $50 \%$ of the samples (figure 6 ). The percentage of mature and ovigerous females was always less than $16 \%$. Females were morphologically recognisable at smaller sizes than males, but males became larger than females. Thus, males predominantly constituted higher size classes. The largest individuals collected presented $2.22 \mathrm{~mm}$ cephalic length $(C L)$ (male) and $2.00 \mathrm{~mm} C L$ (female) at the Fontela station, $2.18 \mathrm{~mm} C L$ (male) and $1.90 \mathrm{~mm} C L$ (female) at the Armazéns station, and $2.20 \mathrm{~mm} \mathrm{CL}$ (male) and $1.88 \mathrm{~mm} C L$ (female) at the Pranto station. By the end of winter, no small individuals were found at the Fontela (north arm) and Pranto (inner area of the south arm) stations, but the same was not observed at Armazéns station. The absence of juveniles in the population appeared clearly related with a decrease in the percentage of ovigerous females (figures 6 ).

\subsection{Reproduction, sex-ratio, and fecundity}

The E. marinus population was sexually active throughout the year in the Mondego estuary. However, taking into account the percentage of ovigerous females over the total female population (figures 6 ), sexual activity decreased at the end of winter, almost ceasing, in both arms. A new increase was observed in spring. A second period during which sexual activity decreased was observed at Fontela during summer.

The percentual variation of eggs in different development stages confirms that sexual activity takes place throughout the year. In fact, eggs in all stages of development were found along the study period. Stepwise multiple regression analysis showed a positive correlation between the percentage of ovigerous females $(\% O F)$ and salinity at the Pranto station $(r=0.39 ; p<0.05)$ :

$$
\ln (1+\% \text { OF })=2.76+0.038 S A L
$$

To confirm in a sounder way that recruitment was continuous, additional sets of samples were collected at the Pranto station with a three days periodicity during a fifteen days period, in winter, and again during a thirty days period, in spring. The methodology used was the same already described. It was possible to confirm that emission of new recruits occurred every day, without any relation with tidal amplitude.

Sex-ratio variation presented a different pattern in the two arms of the estuary. At Fontela females were more abundant than males in autumn and winter while the contrary was observed in spring and summer, namely during the hottest period. In south arm males were almost always more abundant than females, namely during winter, although females outnumbered males during part of the summer and autumn 1995. Stepwise multiple regression analysis showed that the sex ratio (males/females) was positively correlated with water temperature at Fontela sampling station $(r=0.42 ; p<0.05)$ :

$$
\ln (1+\text { Sex }- \text { ratio })=0.45+0.02 \text { TEMP }
$$

and with green macroalgae biomass at Armazéns station $(r=0.51, p<0.01)$ :

$$
\ln (1+\text { Sex }- \text { ratio })=0.61+0.03 \text { GMB }
$$

Despite the fact that individual fecundity was extremely variable, a significant correlation was found between the number of eggs in stage $A B$ within brood pouches and the size of females collected each season. Higher values of fecundity were observed in spring and autumn and lower values in winter and summer figure $7 \mathrm{~A}$ ). The mean volume of eggs $\mathrm{AB}$ was higher during colder months and lower during the summer period (figure $7 B$ ). Stepwise multiple regression analysis indicated that fecundity $(F)$ was positively correlated with salinity $(r=0.45 ; p<0.05)$ :

$$
F=6.30+0.25 S A L
$$

and that $\mathrm{AB}$ egg volume $(\mathrm{ABvol})$ was negatively correlated with temperature and salinity $(r=0.78$; $p<0.0001)$ :

$$
\ln (1+\text { ABvol })=0.95-0.009 \text { TEMP }-0.01 S A L
$$

\subsection{Production estimates}

Length-weight relationships previously established by Marques and Nogueira [27] were used in produc 


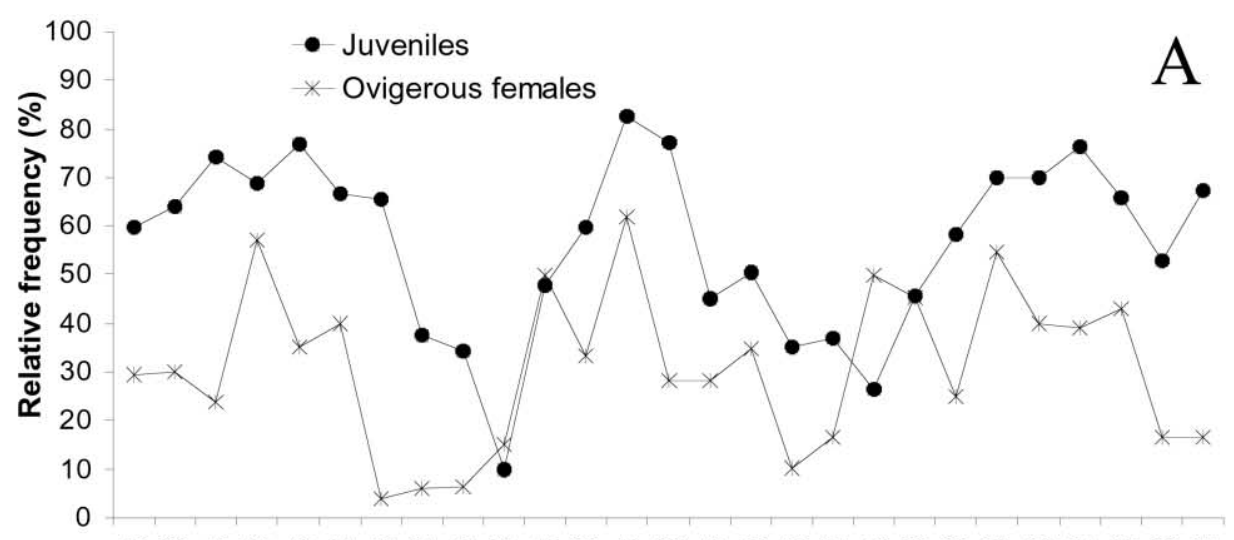

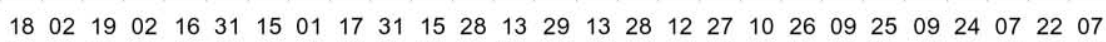
$\begin{array}{lllllllllllllllllllllllllll}11 & 12 & 12 & 01 & 01 & 01 & 02 & 03 & 03 & 03 & 04 & 04 & 05 & 05 & 06 & 06 & 07 & 07 & 08 & 08 & 09 & 09 & 10 & 10 & 11 & 11 & 12\end{array}$

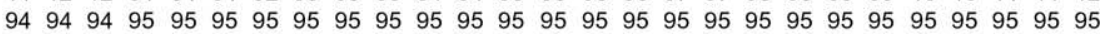
AUT I WINTER I SPRING I SUMMER I AUTUMN

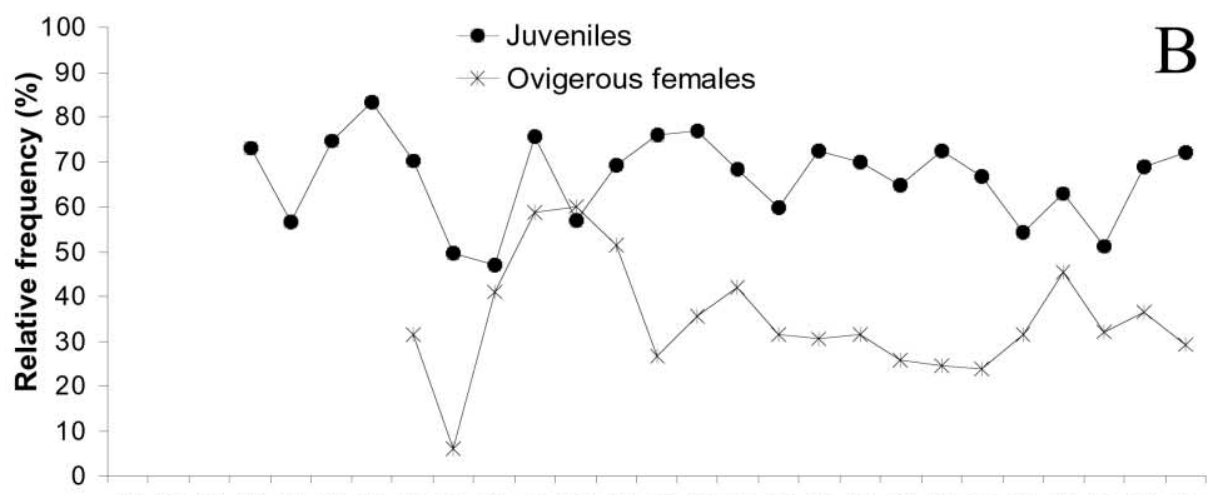

$\begin{array}{lllllllllllllllllllllllllll}18 & 02 & 19 & 02 & 16 & 31 & 15 & 01 & 17 & 31 & 15 & 28 & 13 & 29 & 13 & 28 & 12 & 27 & 10 & 26 & 09 & 25 & 09 & 24 & 07 & 22 & 07\end{array}$ $\begin{array}{lllllllllllllllllllllllllll}11 & 12 & 12 & 01 & 01 & 01 & 02 & 03 & 03 & 03 & 04 & 04 & 05 & 05 & 06 & 06 & 07 & 07 & 08 & 08 & 09 & 09 & 10 & 10 & 11 & 11 & 12\end{array}$

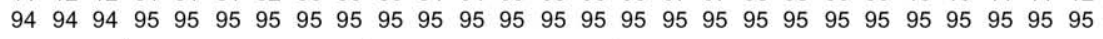
$\begin{array}{llllll}\text { AUT I WINTER I SPRING I SUMMER I AUTUMN } & \end{array}$

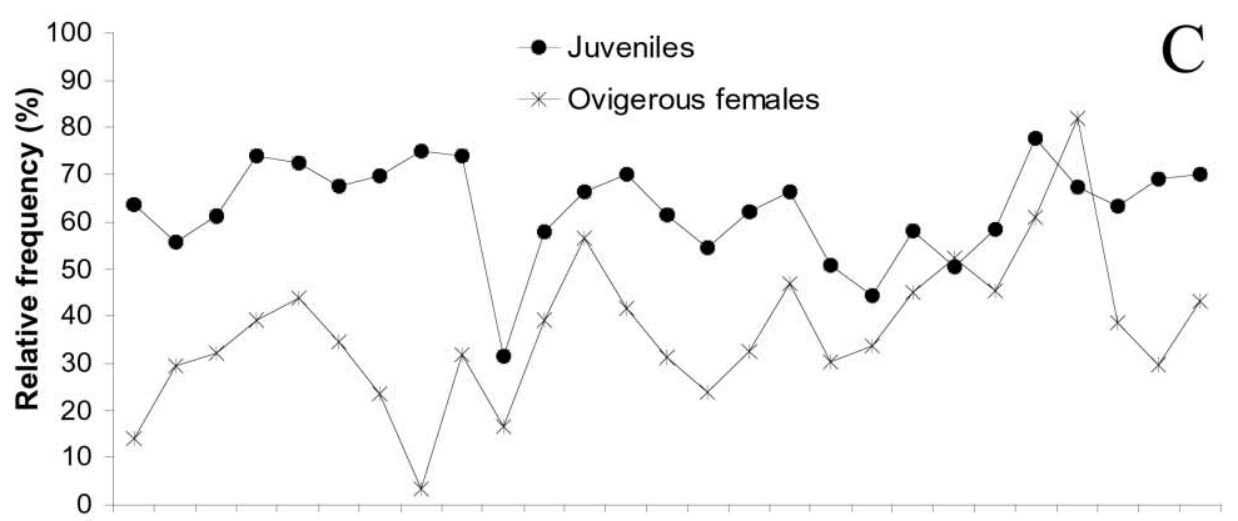

$\begin{array}{lllllllllllllllllllllllllll}18 & 02 & 19 & 02 & 16 & 31 & 15 & 01 & 17 & 31 & 15 & 28 & 13 & 29 & 13 & 28 & 12 & 27 & 10 & 26 & 09 & 25 & 09 & 24 & 07 & 22 & 07\end{array}$

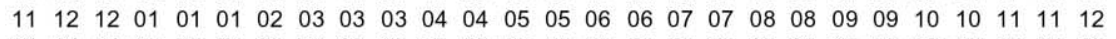
$\begin{array}{lllllllllllllllllllllllllll}94 & 94 & 94 & 95 & 95 & 95 & 95 & 95 & 95 & 95 & 95 & 95 & 95 & 95 & 95 & 95 & 95 & 95 & 95 & 95 & 95 & 95 & 95 & 95 & 95 & 95 & 95\end{array}$
AUT I
WINTER
SPRING
SUMMER ।
AUTUMN

Figure 6. Echinogammarus marinus. Variation of ovigerous females in the total female population and of juveniles in the population. A. Fontela, B. Armazéns, C. Pranto. 


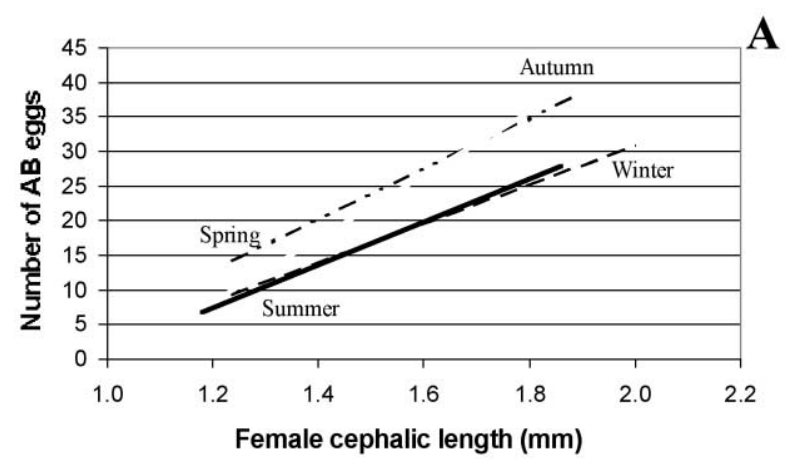

B

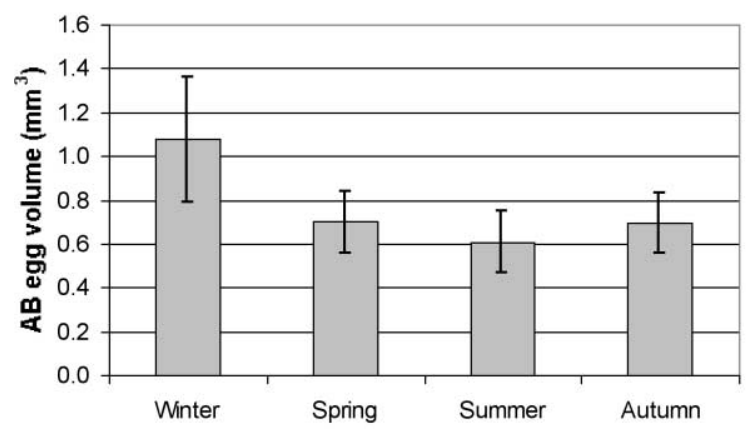

Figure 7. Echinogammarus marinus. Seasonal regression lines of $\mathrm{AB}$ eggs number $(\mathrm{Y})$ on cephalic length $(\mathrm{X})$ of ovigerous females $(\mathrm{A})$ and $\mathrm{AB}$ egg volume (mean $\pm \mathrm{s}$. d.) (B) during the study period.

Table I. Echinogammarus marinus. Production estimates at the three sampling places.

\begin{tabular}{llll}
\hline & $\mathrm{P}$ & $\bar{B}$ & $\mathrm{P} / \bar{B}$ \\
& $\left(\mathrm{~g} \mathrm{AFDW} \cdot \mathrm{m}^{-2} \cdot \mathrm{year}^{-1}\right.$ & $\left(\mathrm{g} \cdot \mathrm{m}^{-2}\right)$ & \\
\hline Fontela & $1.74-2.44$ & 0.39 & $4.14-6.18$ \\
Armazéns & $1.96-2.74$ & 0.42 & $4.68-6.56$ \\
Pranto & $3.85-5.38$ & 0.86 & $4.54-6.36$ \\
\hline
\end{tabular}

tion estimates (table $)$. Production and annual average biomass were higher at the Pranto station, located in south arm, while the lowest values were found at Fontela, in the north arm. Despite these differences, annual $\mathrm{P} / \bar{B}$ ratios were similar in all sampling stations.

\section{DISCUSSION}

\subsection{Abundance}

Population density showed clear seasonal and spatial variation. At the Pranto station, E. marinus population was stable all over the study period, which agrees with results obtained by Marques and Nogueira [27]. This is probably favoured by the fact that muddies sediments with high organic content surround hard substrates at this station. It is well known that $E$. marinus is typically found underneath algae (fucoids) associated with muddy deposits, but less common on clean sands [26, 27, 43]. The Fontela station in north arm is characterised by more coarse sediments, with low content of organic matter, which may explain lower abundance. Lower densities recorded in the beginning of spring at the three sampling stations were due to a drop of recruitment by the end of winter, probably as a response to more harsh conditions. On the contrary, an increase in recruitment was responsible for the significant increase in density observed during spring.

The positive correlation found between $E$. marinus density and green macroalgae biomass at Fontela and Armazéns stations suggests a dependence on the yearly dynamics of that macroalgae. This is consistent with observations on some other amphipod species 5.5 $12,15,22,41]$ Such dependence is probably related with the variation of food resources, since E. marinus can feed directly on algae [13], although it does not ingest fresh Fucus, regarded as unpalatable due to their content of phenolic compounds [42]. The negative correlation between E. marinus density and temperature and salinity at Fontela station may express the fact that higher temperature increases desiccation rates during emersion, intensifying the environmental stress upon organisms in intertidal areas. Salinity does not play a role in this process but higher salinities were also recorded in the warmest period of the year. Juveniles inhabiting the intertidal zone, when emerged, can loose water much faster than adults, since small individuals have greater surface-to-volume ratios [16]. Juveniles are consequently much more vulnerable to desiccation stress than adults. It was observed that, during summer and part of autumn, $E$. marinus density reached the lowest values in the north arm. This was probably due to the different hydrographic characteristics of the two arms that caused organisms living in the intertidal area of the north arm to spend more time in emersion.

In the south arm, between the autumn of 1994 and the winter of $1995, E$. marinus density was very different at the two sampling stations. During this period, the Pranto station exhibited higher densities while the $\mathrm{Ar}$ mazéns station attained its lowest values. The Armazéns sampling station is located in the confluence of the Armazéns channel with the south arm (figure d). There is no freshwater discharge in this channel but the tidal wave washes out the channel, where wastewaters from several industries are discharged [14]. Although the available data are not consistent enough to demon 
strate it, a possible explanation for E. marinus density variations is that individuals moved upstream, from the Armazéns to the Pranto area, to avoid extreme conditions during this period.

E. marinus densities recorded during this study were lower than those found by Marques and Nogueira [27] $\left(500\right.$ to $4000 \mathrm{ind} \cdot \mathrm{m}^{-2}$ ). This may signify a decline of the E. marinus population in the Mondego estuary, which could be explained by an eventual decrease of the area occupied by $F$. vesiculosus during the last years. Although there are no previous data on $F$. vesiculosus biomass in the Mondego estuary, considerable changes in environmental conditions, like periodic dredging, namely in the north arm, discharge of domestic effluents, discharge of waters contaminated with pesticides (never quantified) proceeding from rice fields located upstream, and eutrophication could be reasons for the decrease of both $F$. vesiculosus and $E$. marinus populations.

\subsection{Reproduction, sex-ratio, and fecundity}

E. marinus ovigerous females were found all over the year in the Mondego estuary, as referred by Marques and Nogueira [27] and the recruitment was continuous. Continuous sexual activity during the year is a common feature in amphipods $[5,6,12,17,36$ 41]. In a previous work, Marques and Nogueira [2] tried to recognise and track cohorts, justifying their approach based on the assumption that, although sexual activity was continuous, juveniles release was synchronised with spring tides, when conditions for juveniles survival were optimised. It appeared to us now that this assumption was not correct, and therefore that cohort recognition would not be a suitable approach. Therefore, we were not able to estimate growth rates and life span from field data. In the Mondego estuary, the southern limit of the known distribution of E. marinus, this species reproduce throughout the year, having probably a multivoltine life cycle. In fact, an experimental study showed that ovigerous females appeared in the population after 8 to 12 weeks of development, and each female could produce at least three broods consecutively (unpublished data). Other E. marinus populations also show different life cycles, varying from univoltine, in a cold-temperate to sub-polar climate (Denmark), with a reproduction period from April to May/June [47], to bivoltine in a maritime temperate climate (Normandy), with a reproduction period from May to July [43]. Actually, this is a common phenomenon among amphipods, which may exhibit large intraspecific variations of life cycles as a function of latitude [11. 18.46.53] probably because a lack of extreme temperatures, especially cold temperatures, might allow prolonged reproduction periods [19] A period where sexual activity almost ceased was ob- served in the Mondego estuary population, by the end of the winter, although this was almost imperceptible at the Armazéns station. Low water salinity tends to induce lower viability of E. marinus eggs [51]. This may explain the decrease of $E$. marinus ovigerous females observed by the end of winter at the Fontela and Pranto stations actually following a period of low salinity. On the other hand, higher salinities values recorded at Armazéns, during the same period, probably allowed the completion of egg embryonic development and the release of juveniles. Therefore, the occurrence of higher salinities allowed in general the occurrence of higher percentage of ovigerous females. Marques and Nogueira [27] also related a period of low sexual activity during the first year of their study, but not in the second year. A possible explanation is the fact that temperature and salinity were lower during that period in the first year. Therefore, a decrease in the reproduction effort might have been a response of $E$. marinus population to more harsh conditions.

Males outnumbered females, notably during spring and summer in the north arm, and during the winter in the south arm. This is not a common feature with other amphipod species populations $[1,6-10,18,41,42]$, neither with other E. marinus populations [47] The previous study by Marques and Nogueira [27] also related a sex ratio favourable to females in E. marinus. Mechanisms that generate male-biased sex ratios in $E$. marinus are not known. Stepwise multiple regression analysis suggested that higher temperatures and bigger biomass of green macroalgae could influence positively a predominance of males, but does not explain what could be the causal relation. On the other hand, differential rates of growth, maturation, longevity or predation can all result in skewed sex ratios [1]. Watt [52] showed that photoperiod influence the sex ratio of Gammarus duebeni, with preponderance of males when exposed to long days (>13-14 h light), and preponderance of females on exposure to short days $(<13-14 \mathrm{~h}$ light $)$ at $15^{\circ} \mathrm{C}$. Kneib [20] suggest that temporal variations in the sex ratio in Uhlorchestia spartinophila populations could be influenced by differential mortality caused by seasonal changes in the quality or availability of food. Moore [35] related a substantial swing in sex ratio from season to season in Lembos websteri, involving a winter period of male domination, giving way in the spring and summertime either to female domination or to a ratio close to unity. Parasitism by microsporidians can also alter sex ratios of Gammarus duebeni populations by causing sex transformation (Bulnheim in Conlan [4]). Finally, male sexual maturity is relatively difficult to determine and since immature females are included in sex ratio estimations, it is acknowledged that the ratios quoted do not represent the real operational sex ratio of reproductively competent individuals 1 . 
Fecundity of females of similar size was quite variable which could be due to constraints during sampling and sorting in the laboratory. In fact, Drake \& Arias [12] reported the tendency of preserved females to lose their broods. However, significant correlation was found between number of eggs in stage $\mathrm{AB}$ within brood pouches and size of females. A positive relationship between fecundity and hody size is indeed common in amphipods $[1,5,7,8,9,10,15$ 17. 22, 27, 42, 50]. Northern Gammaridea species usually produce smaller clutches during the colder months, associated with an increase in egg size, giving the offspring a better chance of surviving harsh conditions $[21,41,48,50]$ This was also observed in $E$. marinus. However, in our case, the number of eggs produced per female was similar in winter and summer, although we observed, in an experimental study (unpublished data), that E. marinus females reared at $20{ }^{\circ} \mathrm{C}$ presented smaller broods and shorter periods of embryonic development when compared with females cultivated at lower temperatures $\left(10^{\circ} \mathrm{C}\right)$. A possible interpretation is that E. marinus females had smaller broods during colder months because egg volume was higher, while in summer broods were smaller probably as a consequence of shorter periods of embryonic development, which allowed production of more broods in the same period of time. Stepwise multiple regression analysis showed a positive correlation between fecundity and salinity. As said above, Vlasblom $\&$ Bolier [51] found that lower viability of the eggs in E. marinus was related to egg swelling at low salinities due to water intake by osmosis. Early developmental stages are especially vulnerable at low salinities, suggesting that any osmoregulatory ability, whether due to active transport or reduced membrane permeabilities, do not appear until later on 37$]$ A negative correlation between $\mathrm{AB}$ egg volume and temperature and salinity was observed by us. In colder months (normally associated to lower salinities, essentially due to rainfall), developing embryos presented bigger volumes, which may optimise chances of survivorship because they contain more reserves. With higher temperatures and salinities embryos may probably survive easier, and therefore such conditions favour the production of smaller eggs by E. marinus females.

\subsection{Production estimates}

Production values estimated presented spatial variations. Production and annual average biomass were higher in the Pranto station (south arm), where density was also higher, while the lowest values were recorded at Fontela (north arm), also associated with lower abundances. Differences in annual production of $E$. marinus in the Mondego estuary were essentially due to differences in population density, but annual $\mathrm{P} / \bar{B}$ ratios were similar at all sampling places. Annual $\mathrm{P} / \bar{B}$ ratios estimated can be considered relatively high when compared with values obtained to other amphipod species from temperate zones $[3,7,8-10,18,44]$, and also to Cyathura carinata, an isopod species considered important to the structure and functioning of the Mondego estuary biological community [30] (table I I ). However, the fact that different methods were used to estimate secondary production in each

Table II. Production estimates of some amphipod and one isopod species.

\begin{tabular}{|c|c|c|c|}
\hline Species, Location & Production $\left(\mathrm{g} \cdot \mathrm{m}^{-2} \cdot \mathrm{yr}^{-1}\right)$ & $\mathrm{P} / \bar{B}$ & Source \\
\hline \multicolumn{4}{|l|}{ Ampelisca araucana } \\
\hline Chile & $8.03-12.43$ (DW) & $3.65-4.45$ & [3] \\
\hline \multicolumn{4}{|l|}{ A. tenuicornis } \\
\hline English Channel & $0.70-1.68(\mathrm{DW})$ & $3.12-4.20$ & [7] \\
\hline \multicolumn{4}{|l|}{ A. typica } \\
\hline English Channel & $0.07-0.16$ (DW) & $4.06-4.36$ & [9] \\
\hline \multicolumn{4}{|l|}{ A. armoricana } \\
\hline English Channel & $0.12(\mathrm{DW})$ & $1.76-2.74$ & {$[10]$} \\
\hline \multicolumn{4}{|l|}{ A. brevicornis } \\
\hline English Channel & $0.04-0.49(\mathrm{DW})$ & $2.15-2.80$ & [8] \\
\hline England & $1.31-1.68(\mathrm{DW})$ & $2.49-3.21$ & {$[20]$} \\
\hline \multicolumn{4}{|c|}{ Corophium curvispinum } \\
\hline The Netherlands & 5.85-11.26 (AFDW) & $2.7-3.5$ & {$[44]$} \\
\hline \multicolumn{4}{|c|}{ Cyathura carinata (Isopoda) } \\
\hline Portugal & 5.7-9.9 (AFDW) & $1.65-2.03$ & {$[30]$} \\
\hline
\end{tabular}

DW - dry weight; AFDW - ash-free dry weight. 
case makes a sound comparison difficult. But the ample intertidal distribution of E. marinus, its accessibility to aquatic predators and birds, and high turnover rates suggest that this amphipod may play an important role in the trophic dynamics of the Mondego estuary community.

\section{CONCLUSION}

Evidence is shown that E. marinus population distribution, dynamics and annual production in the Mondego estuary were affected by the hydraulic regime. Temperature, salinity, and green macroalgae biomass also influenced the E. marinus population. In the north arm, where dredging takes place regularly and environmental conditions are characterised by coarse sediments and stronger daily changes in salinity [28, 29], E. marinus shows the lowest values of density and annual production. On the contrary, in the south arm, characterised by a weaker hydraulic regime, muddy sediments and smaller daily salinity changes [28, 29] E. marinus presents higher densities and annual production, namely in the inner areas. The present results showed that in the southern limit of the species the recruitment is continuous through the year and, as a consequence, no cohorts are distinguished on the population. This information clearly reports new insight of the species, in opposition to the previous study, which assumed a discontinuous recruitment occurring only in spring tides. The generalised notion that estuaries are highly productive systems is reinforced by these results and, in the case of the Mondego, E. marinus may definitively be seen as an important element of this energy flow.

Acknowledgments. The present work was supported by JNICT/FCT (Portuguese National Institution for Scientific Research) by a Ph.D. grant (FMRH/BD/822/93 - PRAXIS $\mathrm{XXI} / \mathrm{BD} / 14652 / 97)$. The authors are indebted to all colleagues who assisted in field and laboratory work.

\section{REFERENCES}

[1] Beare D.J., Moore P.G., The distribution and reproduction of Pontocrates arenarius and P. altamarinus (Crustacea: Amphipoda) at Millport, Scotland, J. Mar. Biol. Ass. UK 76 (1996) 931-950.

[2] Benke A.C., A modification of the Hynes method for estimating secondary production with particular significance for multivoltine populations, Limnol. Oceanogr. 24 (1979) 169-171.

[3] Carrasco F.D., Arcos D.F., Life history and production of a cold-temperate population of the sublittoral amphipod Ampelisca araucana, Mar. Ecol. Prog. Ser. 14 (1984) 245-252.
[4] Conlan K.E., Amphipod crustaceans and environmental disturbance: a review, J. Nat. Hist. 28 (1994) 519-554.

[5] Costa F.O., Costa M.H., Life history of the amphipod Gammarus locusta in the Sado estuary (Portugal), Acta Oecol. 20 (1999) 305-314.

[6] Covi M.P., Kneib R.T., Intertidal distribution, population dynamics and production of the amphipod Uhlorchestia spartinophila in a Georgia, USA, salt marsh, Mar. Biol. 121 (1995) 447-455.

[7] Dauvin J.C., Biologie, dynamique et production de populations de crustacés amphipods de la Manche Occidentale. 1. Ampelisca tenuicornis Liljeborg, J. Exp. Mar. Biol. Ecol. 118 (1988) 55-84.

[8] Dauvin J.C., Biologie, dynamique et production de populations de crustacés amphipods de la Manche Occidentale. 2. Ampelisca brevicornis (Costa), J. Exp. Mar. Biol. Ecol. 119 (1988) 213-233.

[9] Dauvin J.C., Biologie, dynamique et production de populations de crustacés amphipods de la Manche Occidentale. 3. Ampelisca typica (Bate), J. Exp. Mar. Biol. Ecol. 121 (1988) $1-22$.

[10] Dauvin J.C., Life cycle, dynamics and productivity of Crustacea-Amphipoda from the western English Channel. 4. Ampelisca armoricana Bellan-Santini et Dauvin, J. Exp. Mar. Biol. Ecol. 123 (1988) 235-252.

[11] Donn T.E. Jr, Croker R.A., Life-history patterns of Haustorius canadensis (Crustacea, Amphipoda) in northern New England, Can. J. Zool. 64 (1986) 99-104.

[12] Drake P., Arias A.M., Distribution and production of Microdeutopus gryllotalpa (Amphipoda: Aoridae) in a shallow coastal lagoon in the Bay of Cádiz, Spain, J Crustac Biol 15 (1995) 454-465.

[13] Duffy J.E., Hay M.E., Food and shelter as determinants of food choice by an herbivorous marine amphipod, Ecology 72 (1991) 1286-1298.

[14] Flindt M.R., Kamp-Nielsen L., Marques J.C., Pardal M.A., Bocci M., Bendoricho G., Nielsen S.N., Jørgensen S.E., Description of the three shallow estuaries: Mondego River (Portugal), Roskilde Fjord (Denmark) and the Lagoon of Venice (Italy), Ecol Model 102 (1997) 17-31.

[15] Fredette T.J., Diaz R., Life history of Gammarus mucronatus Say (Amphipoda: Gammaridae) in warm temperate estuarine habitats, York River, Virginia, J. Crustac. Biol. 6 (1986) 57-78.

[16] Gosselin L.A., Qian P.Q., Juvenile mortality in benthic marine invertebrates, Mar. Ecol. Prog. Ser. 146 (1997) 265-282.

[17] Greenstein D.J., Tiefenthaler L.L., Reproduction and population dynamics of a population of Grandidierella japonica (Stephensen) (Crustacea: Amphipoda) in Upper Newport bay, California, Bull. Southern California Acad. Sci. 96 (1997) 34-42.

[18] Hastings M.H., The life cycle and productivity of an intertidal population of the amphipod Ampelisca brevicornis, Estuar Coastal Shelf Sci 12 (1981) 665-677.

[19] Kalejta B., Hockey P.A.R., Distribution, abundance and productivity of benthic invertebrates at the Berg River estuary, South Africa, Estuar Coastal Shelf Sci 33 (1991) 175-191.

[20] Kneib R.T., Newell S.Y., Hermeno H.T., Survival, growth and reproduction of the salt-marsh amphipod Uhlorchestia spartinophila reared on natural diets of senescent and dead Spartina alterniflora leaves, Mar. Biol. 128 (1997) 423-431.

[21] Kolding S., Fenchel T.M., Patterns of reproduction in different 
populations of five species of the amphipod genus Gammarus, Oikos 37 (1981) 167-172.

[22] LaFrance K., Ruber E., The life cycle and productivity of the amphipod Gammarus mucronatus on a northern Massachussetts salt marsh, Limnol. Oceanogr. 30 (1985) 1067-1077.

[23] Legendre L., Legendre P., Numerical ecology, (2nd edition), Development in Environmental Modelling, 20, Elsevier, Amsterdam, 1998.

[24] Lillebø A.I., Pardal M.A., Marques J.C., Population structure, dynamics and production of Hydrobia ulvae (Pennant) (Mollusca: Prosobranchia) along an eutrophication gradient in the Mondego estuary (Portugal), Acta Oecol 20 (1999) 289-304.

[25] Maren M.J., Some notes on the intertidal gammarids (Crustacea, Amphipoda) from the Atlantic coast of the Iberian Peninsula, Beaufortia 23 (1975) 153-168.

[26] Maren M.J., The biology of Chaetogammarus marinus (Leach) and Eulimnogammarus obtusatus (Dahl), with some notes on other intertidal gammarid species (Crustacea, Amphipoda), Bijdr. Dierk. 45 (1975) 204-224.

[27] Marques J.C., Nogueira A., Life cycle, population dynamics and production of Echinogammarus marinus (Leach) (Amphipoda) in the Mondego estuary (Portugal), Oceanol Acta 11 (1991) 213-223.

[28] Marques J.C., Rodrigues L.B., Nogueira A., Intertidal macrobenthic communities structure in the Mondego estuary (Western Portugal): Reference situation, Vie Milieu 43 (1993) 177-187.

[29] Marques J.C., Maranhão P., Pardal M.A., Human impact assessment on the subtidal macrobenthic community structure in the Mondego estuary (western Portugal), Estuar. Coast. Shelf Sci. 37 (1993) 403-419.

[30] Marques J.C., Martins I., Teles-Ferreira C., Cruz S., Population dynamics, life history, and production of Cyathura carinata (Krøyer) (Isopoda: Anthuridae) in the Mondego estuary, Portugal, J. Crustac. Biol 14 (2) (1994) 258-272.

[31] Marques J.C., Pardal M.A., Nielsen S.N., Jørgensen S.E., Analysis of the properties of energy and biodiversity along an estuarine gradient of eutrophication, Ecol. Model. 102 (1997) 155-167.

[32] Martins I., Marques J.C., Jørgensen S.E., Nielsen S.N., Modelling the effects of green macroalgae blooms on the population dynamics of Cyathura carinata (Crustacea: Isopoda) in an eutrophicated estuary, Ecol. Model. 102 (1997) 33-53.

[33] Medernach L., Grémare A., Comparaison de méthodes d'évaluation de la production secondaire d'une population de l'annélide polychète Ditrupa arietina (O. F. Muller), Oceanol. Acta 22 (1999) 337-352.

[34] Menzie C.A., A note on the Hynes method of estimating secondary production, Limnol. Oceanogr. 25 (1980) 770-773.

[35] Moore P.G., The life histories of the amphipods Lembos websteri Bate and Corophium bonnellii Milne Edwards in kelp holdfasts, J. Exp. Mar. Biol. Ecol. 49 (1981) 1-50.

[36] Moore P.G., Wong Y.M., Observations on the life history of Orchomene nanus (Krøer) (Amphipoda: Lysianassoidea) at Millport, Scotland as deduced from baited trapping, J. Exp. Mar. Biol. Ecol. 195 (1996) 53-70.

[37] Morrit D., Spicer J.I., The culture of eggs and embryos of amphipod crustaceans: implications for brood pouch physiology, J. Mar. Biol. Ass. UK 76 (1996) 361-376.

[38] Múrias T., Cabral J.A., Marques J.C., Goss-Custard J.D., Short-term effects of intertidal macroalgal blooms on the macrohabitat selection and feeding behaviour of waders in the Mondego estuary (West Portugal), Estuar. Coast. Shelf Sci. 43 (1996) 677-688.

[39] Múrias T., Cabral J.A., Lopes R., Marques J.C., Low-water use of the Mondego estuary (West Portugal) by waders (Charadrii), Ardeola 44 (1997) 79-91.

[40] Pardal M.A., Impacto da eutrofização nas comunidades macrobentónicas do Braço Sul do estuário do Mondego (Portugal), Ph.D. thesis, Universidade de Coimbra, Coimbra, 1998.

[41] Pardal M.A., Marques J.C., Metelo I., Lillebø A.I., Flindt M.R., Impact of eutrophication on the life cycle, population dynamics and production of Ampithoe valida (Amphipoda) along an estuarine spatial gradient (Mondego estuary, Portugal), Mar. Ecol. Prog. Ser. 196 (2000) 207-219.

[42] Persson L.E., Grothw and reproduction in two brackish water populations of Orchestia gammarellus (Amphipoda: Talitridae) in the Baltic Sea, J. Crustac. Biol. 19 (1) (1999) 53-59.

[43] Pinkster S., Broodbakker N.W., The influence of environmental factors on distribution and reproductive success of Eulimnogammarus obtusatus (Dahl, 1938) and other estuarine gammarids, Crustaceana 6 (1980) 225-241.

[44] Rajagopal S., van der Velde G., Paffen B.G.P., Bij de Vaate A., Growth and production of Corophium curvispinum G. O. Sars, 1985 (Amphipoda), an invader in the Lower Rhine, in: Schram F.R., von Vaupel Klein C. (Eds.), Crustaceans and the Biodiversity Crisis. Brill, Leiden, 1999, pp. 457-472.

[45] Rohlf F.J., NTSYS-pc 1.80: Numerical taxonomy and multivariate analysis system, Exeter software, New York, 1990, pp. 751-1203.

[46] Sainte-Marie B., A review of the reproductive bionomics of aquatic gammaridean amphipods: variation of the life history traits with latitude, depth, salinity and superfamily, Hydrobiologia 223 (1991) 189-227.

[47] Skadsheim A., The ecology of intertidal amphipods in the Oslofjord. The life cycles of Chaetogammarus marinus e $C$. stoerensis, Mar. Ecol. 3 (1982) 213-224.

[48] Skadsheim A., Coexistence and reproductive adaptations of amphipods: the role of environmental heterogeneity, Oikos 43 (1984) 94-103.

[49] Valiela I., Marine ecological processes, 2nd edition, SpringerVerlag, New York, 1995.

[50] Van Dolah R.F., Bird E., A comparison of reproductive patterns in epifaunal and infaunal gammaridean Amphipoda, Estuar. Coast. Shelf Sci. 11 (1980) 593-604.

[51] Vlasblom A.G., Bolier G., Tolerance of the embryos of Marinogammarus marinus and Orchestia gammarella to lowered salinities, Neth. J. Sea Res. 5 (1971) 255-268.

[52] Watt P.J., Parental control of sex ratio in Gammarus duebeni, an organism with environmental sex determination, J. Evol. Biol. 7 (1994) 177-187.

[53] Wildish D.J., Secondary production of four sublitoral, softsediment amphipod populations in the Bay of Fundy, Can. J. Zool. 62 (1984) 1027-1033. 